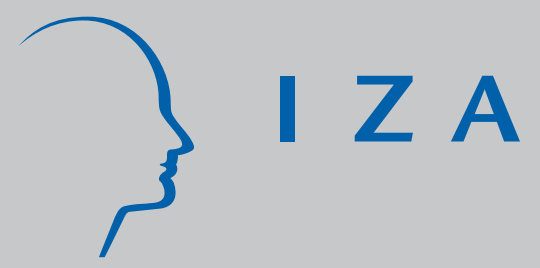

IZA DP No. 170

Immigration Policy in Integrated

National Economies

Thomas K. Bauer

Klaus F. Zimmermann

J uly 2000 


\title{
Immigration Policy in Integrated National Economies
}

\author{
Thomas K. Bauer \\ CEPR, London and IZA, Bonn
}

Klaus F. Zimmermann

Bonn University, DIW, Berlin, CEPR, London and IZA, Bonn

Discussion Paper No. 170
July 2000

\author{
IZA \\ P.O. Box 7240 \\ D-53072 Bonn \\ Germany \\ Tel.: +49-228-3894-0 \\ Fax: +49-228-3894-210 \\ Email: iza@iza.org
}

This Discussion Paper is issued within the framework of IZA's research area Mobility and Flexibility of Labor Markets. Any opinions expressed here are those of the author(s) and not those of the institute. Research disseminated by IZA may include views on policy, but the institute itself takes no institutional policy positions.

The Institute for the Study of Labor (IZA) in Bonn is a local and virtual international research center and a place of communication between science, politics and business. IZA is an independent, nonprofit limited liability company (Gesellschaft mit beschränkter Haftung) supported by the Deutsche Post AG. The center is associated with the University of Bonn and offers a stimulating research environment through its research networks, research support, and visitors and doctoral programs. IZA engages in (i) original and internationally competitive research in all fields of labor economics, (ii) development of policy concepts, and (iii) dissemination of research results and concepts to the interested public. The current research program deals with (1) mobility and flexibility of labor markets, (2) internationalization of labor markets and European integration, (3) the welfare state and labor markets, (4) labor markets in transition, (5) the future of work, (6) project evaluation and (7) general labor economics.

IZA Discussion Papers often represent preliminary work and are circulated to encourage discussion. Citation of such a paper should account for its provisional character. 
IZA Discussion Paper No. 170

July 2000

\section{ABSTRACT \\ Immigration Policy in Integrated National Economies*}

Migration is an unavoidable aspect of globalization. While full flexibility is politically unfeasible, the paper argues for regulated openness. Migration in the age of globalization should be judged according to the labor market needs of the receiving countries. This would also serve best the demands of political leaders that seek reelection. Voters are happier with migrants if they are largely selected according to their value to the economy. In the current situation in developed countries it is best to select skilled migrants, and those who can produce non-tradable services. The need to import skilled labor might be limited by virtual migration through the Internet.

JEL Classification: J61, J68

Keywords: Migration policy, globalization

Klaus F. Zimmermann

IZA

P.O. Box 7240

D-53072 Bonn

Germany

Tel.: +492283894200

Fax: +492283894210

Email: zimmermann@iza.org

\footnotetext{
* Prepared for the American Institute for Contemporary German Studies (AICGS) project on Regulating the Post-Westphalian World: The Politics of Globalization in Germany and the United States, Washington D.C., USA. We are grateful to the participants of AICGS project meetings, Carl Lankowski and Rainer Winkelmann for insightful comments and suggestions on earlier drafts.
} 


\section{INTRODUCTION}

The current debate on the growth of the global economy has mainly dealt with the increased trade flows in the 1980s and 1990s induced by global reductions of trade barriers, the rapid transmission of technology across countries, and highly mobile capital. An increasing literature analyzes various aspects of the effects of integrated economies, i.e. the effects of globalization on welfare, labor market, and inequality. ${ }^{1}$ The question of increased mobility of labor, however, has been widely neglected in the debate on integration in the world economies, even though it is an essential part of globalization.

Comparable to the increased world trade flows, OECD countries experienced rising immigration flows in the 1980s and the beginning of the 1990s. Figure 1 elucidates this development for selected OECD countries. In all countries immigration increased strongly in the late 1980 s up to about 1993. Then the growth in immigration stopped and almost all countries exhibit a negative trend in the immigration flows. Given these numbers and the growing discussion about the economic effects of globalization several questions arise. Is there a link between the increased international mobility of goods, technology, and capital, and the development in international migration? Are there similarities in the economic effects of globalization and labor migration? Can we trace recent changes in immigration policy to the economic effects of globalization?

In the following section we discuss theoretical and empirical investigations of the link between the growth of the global economy and the mobility of labor. Furthermore, we will provide a theoretical and empirical comparison of the labor market effects of globalization and the immigration of labor. In Section 3 we analyze the German immigration policy in the last decade with a special emphasis on the different sentiments of the German population towards trade and immigration and the current policy concepts of the most relevant German 
parties. In Section 4 we discuss an immigration policy that seems crucial to deal with the economic effects of a globalized economy. Section 5 concludes.

\section{Globalization AND the Migration OF LAbor}

\subsection{Trade and migration}

The development of increasingly integrated economies is largely characterized by the reduction of global trade barriers resulting in increased trade of commodities and capital mobility, the transmission of technology across countries, and the development of multinational firms that can produce and hire labor almost all over the world. In the following, we discuss the theoretical links between these developments and labor migration and survey the existing empirical evidence on the relationship between trade and migration.

According to the standard economic model, trade is a substitute for international migration. According to the Heckscher-Ohlin model of factor price equalization, the removal of trade barriers leads to the countries' specialization in production of the goods for which they have relatively abundant supply of input factors and thus have a comparative cost advantage. Consider two countries, a developed country with many skilled workers compared to unskilled workers, and a developing country with many unskilled workers relative to skilled workers. Assume further that there are two goods, one that is produced by skilled and one that is produced by unskilled workers. Producers in both countries have the same technology. In this setting trade is determined by the factor endowments of the two countries: the developed (developing) country will import the good which is produced by unskilled (skilled) workers and specialize in the production of the good produced by skilled (unskilled) workers. Trade between these two countries will decrease the wages of unskilled workers in the developed country and increase the wages of skilled workers, and vice versa for the developing country. In the long-run and under specific assumptions ${ }^{2}$, the factor prices for

\footnotetext{
$2 \quad$ See Bhagwati and Dehejia (1994) and Martin and Taylor (1996) for a discussion of these assumptions.
} 
skilled and unskilled workers across the two countries are equalized. In general, this basic model states that trade or the mobility of production factors between countries will result in equalized factor prices. However, if factor prices are equalized, the incentive to migrate disappears. Hence, trade can be seen as a substitute for international migration.

The empirical evidence on factor price equalization and the substitutional relationship between labor migration and trade is not as clear as it appears in the theoretical model. ${ }^{3}$ Several empirical studies found that trade and migration are complements instead of substitutes, at least in the short and medium run. ${ }^{4}$ Two lines of arguments have been brought forward to explain these empirical results. First, our understanding of the determinants of international migration is far from being complete. ${ }^{5}$ Existing empirical evidence shows that expected wage differentials have a significant effect whenever we observe large migration flows between two countries. However, the reverse conclusion is not obvious, since we cannot observe large migration flows whenever huge wage differentials are present. Furthermore, theoretical models of the migration decision suggest that the desire to overcome capital constraints and income risks in less developed countries could lead to international migration flows even in the absence of expected wage differentials (Stark, 1991).

Second, the assumptions underlying the factor prize equalization theorem are questioned frequently and empirical studies on the effect of increased trade on factor prices provide no clear picture on whether trade leads to an equalization of factor prices. ${ }^{6}$ One of the most restrictive assumptions is that developed and less developed countries have access to the same production technology. Political stability, infrastructure, technological advantages, or scale economies can offset the comparative advantage of developing countries in the production of labor-intensive commodities. Political instability and market imperfections in

\footnotetext{
3 See Schiff (1996) for a discussion of the standard trade model and the question whether there is a substitutional or complementary relationship between trade and migration. Rotte and Vogler (1998) provide a recent review.

See Bauer and Zimmermann (1998) for a recent survey of theoretical and empirical analyses of migration.
} 
developing countries can hinder factor price equalization and provide additional migration incentives. As predicted by the basic model, trade liberalization creates new employment and higher earnings in the developing countries, giving individuals and families the means to finance migration that they could not afford in the past. Furthermore, there is increasing evidence that, once individuals migrated from a particular sending to a particular receiving country, migration becomes a self-perpetuating process, because the costs and risks of migration are lowered by social and informational networks (Bauer and Zimmermann, 1998; Massey, 1990). Finally, there are forces in the globalization process, which could diminish the substitutional relationship between trade and migration. New informational technologies and trade itself provides potential migrants with more and better information concerning the cost and potential benefits of migration. The availability of better information reduces the risks and costs of migration and therefore fosters migration.

\subsection{Comparing the economic effects of trade and labor migration}

In the last two decades the development of the labor markets in advanced countries where marked by a decreasing demand for low-skilled worker. In the United States this development showed up in falling real wages of low-skilled workers and an increased income inequality. Due to relatively inflexible labor markets, this development resulted in increased unemployment of low-skilled workers in Europe. In the public debate, globalization of the world economy and immigration pressure has been identified as two of the main sources of the decreasing demand for low-skilled workers.

Within the globalization debate, the Heckscher-Ohlin model has been used to explain the unfavorable development of the unskilled labor market. If developed countries import commodities from developing countries produced by unskilled labor and export commodities produced by skilled labor to these countries, the factor price equalization theorem predicts 
decreasing wages of unskilled and rising wages of skilled workers in the developed countries. In the case of downward rigid wages, as in the European context, trade will lead to rising unemployment of unskilled workers and a shortage of skilled workers. However, both explanations of the reduced demand for unskilled labor relative to skilled labor are qualitatively similar to the effects of a skill-biased technological change, and, as we will see below, to the effects of the immigration of unskilled labor.

Empirical analyses of the effects of trade on the labor market essentially follow two different approaches. ${ }^{7}$ One approach is to use data on the factor content of import and export industries to estimate the change in factor endowments that is due to trade. The empirical evidence of these kinds of studies is mixed (Borjas, Freeman and Katz, 1992; Sachs and Shatz, 1992; and Wood, 1994, 1995). The second approach is to use price data to explore whether increased imports from less-developed countries reduce the price of goods produced by low-skilled workers in the developed countries. If this is the case, the demand for unskilled labor in the developed countries will fall and decrease their wages or increase their unemployment. The empirical results using this approach suggest that trade has only a minor impact on the wages and employment of unskilled workers (Freemann, 1995).

The effects of trade on the German labor market have been investigated by Lücke (1996), Haisken-DeNew and Zimmermann (1997), and Winter-Ebmer and Zimmermann (1998). Lücke (1996) cannot identify relevant effects of the relative price of unskilled-labor intensive goods on wages. Haisken-DeNew and Zimmermann (1997) study wage and mobility effects of trade and migration. They find that wages are negatively affected by a relative increase of imports (relative to exports). Winter-Ebmer and Zimmermann (1998) find that trade does not affect wages at all, and hardly affects employment.

Complicated economic processes determine whether one can expect gains from immigration and which groups will receive them. Assuming homogeneous labor, the standard 
competitive framework predicts that immigration will shift out the supply of labor. This shift can readily increase total welfare, but also tends to drive down the wage rate. Under the assumption that labor is heterogeneous, the key issue for the evaluation of the wage and employment effects of immigration on natives is whether foreign workers are substitutes or complements to native workers. In general, one might expect that the higher the substitutability of foreign for domestic workers, the more likely an increase in immigration would cause a decline in the domestic labor force's wages.

More sophisticated theoretical models analyze the labor market effects of immigration with imperfect labor markets in the receiving countries (Brecher and Choudhri, 1987; Schmidt, Stilz, and Zimmermann, 1994; Bauer and Zimmermann, 1997). In the case of minimum wages, which already caused unemployment in the receiving country, increased immigration may just widen the gap between the minimum wage and what would have been the market wage, leading to higher unemployment. Of particular importance in the German context is the case where wages may not be downward flexible due to the behavior of unions. In the theoretical model developed by Schmidt, Stilz, and Zimmermann (1994), which considers heterogeneous labor and downward rigid wages due to the behavior of unions, the labor market effects of immigration depend on the reaction of the union and the degree to which skilled and unskilled labor are complements. In this model, immigration of unskilled labor produces gains for skilled natives, but unskilled natives receive lower wages and face higher unemployment. To what extent natives in total benefit from unskilled immigration depends on the concrete situation, i.e. the reaction of the union and the degree of complementarity between unskilled and skilled labor. In the case of immigration of skilled labor, both wages and unemployment of natives will decline, and total income of natives will increase.

See Freeman (1995) for a detailed description of these approaches and a discussion of their advantages and problems. 
The existing empirical literature on the labor market effects of immigration can be differentiated into studies using simulation methods and those using an econometric approach. ${ }^{8}$ Calibrating the model of Schmidt, Stilz, and Zimmermann (1994) using German data for 1993, Bauer and Zimmermann (1997) showed that in the case of unskilled immigration of $10 \%$ of the German labor force in 1993, income losses of natives could reach up to $5 \%$ of national income. In the case of skilled immigration there could be substantial gains due to the improvement of the employment possibilities of unskilled natives (up to $4 \%$ of national income at the unemployment rates of 1993). Furthermore, they showed that the distributional effects of immigration could be quite dramatic. It appears that capital always benefits from immigration and that these benefits increase with the share of skilled immigrants. Both types of labor could loose very much from immigration depending on the share of immigrants that substitute them. For instance, if $10 \%$ of the native work force immigrates and all immigrants are skilled, skilled native workers win $5.4 \%$ of their initial income. The loss of unskilled native workers is calculated to reach DM 62 billion or 21\% of their initial income in the case of unskilled immigration.

An increasing literature analyzes the wage and employment effects of immigration using econometric techniques. Most of these studies find that immigration hardly affects the wages and employment prospects of natives, at least not negatively (Bauer et. al., 1998). It should be noted that similar studies in the U.S. mostly were unable to find remarkably negative effects of immigration on the labor market situation of natives (Friedberg and Hunt, 1995).

\section{German Migration Policy}

There is an increasing literature provided by economic historians arguing that the convergence of living standards across countries in the period between 1850 and 1914 have

8 See Bauer (1998), Bauer et.al. (1998), and Zimmermann (1994, 1995, 1997) for various surveys. 
been the result of a globalization process similar to the process we observe since the 1980s (Williamson, 1998). This literature also shows that the economic effects of the globalization process in the second half of the nineteen's century were similar to those we have observed in the 1980s and 1990s, namely a significantly increasing inequality. Williamson (1998) argues that this development caused a more restrictive immigration and trade policy prior to World War I. In this section we give a short description of past and current issues in the German migration policy with a special emphasis on the different policy approaches of the main German parties and the sentiments of the German population towards trade and migration.

\subsection{German migration policy in the last decade}

From 1988 to 1992 Germany experienced a sharp increase in immigration flows (see Figure 1). Figure 2 shows the structure of the immigration flow to Germany since 1988 by immigration status. It appears that immigration between 1988 and 1996 has been dominated by east-west migration and by a heavy inflow of asylum seekers and refugees. A large part of the east-west migrants were ethnic Germans, who moved directly to Germany. Since 1989 Germany also receives so called "New Labor Migrants" which consists of temporary migrants (Werkvertragsarbeiter, Seasonal Workers, and Gastarbeitnehmer) who immigrate through special bilateral agreements Germany signed with several East European countries. ${ }^{9}$

Since 1992, immigration to Germany decreased again due to a more restrictive immigration policy of the German government, consisting of a coalition between the $\mathrm{CDU} / \mathrm{CSU}$ and the FDP. Figure 2 shows that this decrease could be mainly traced back to a decreased number of asylum seekers and Aussiedler, which is the result of changes in the immigration policy directed towards these group of migrants. In 1993, the government changed the asylum law to establish the possibility to send back asylum seekers immigrating

$9 \quad$ See Bauer and Zimmermann (1997) for a detailed discussion of this type of temporary immigration. 
from member states of the European Union or from other safe countries defined in the new law. As safe countries surround Germany, asylum seekers theoretically could enter Germany only by air or sea. The decrease in the immigration of Aussiedler is due to administrative barriers set up by the German government since 1990. Since July 1990, ethnic Germans have to apply for immigration in the countries of origin. In 1993, a new law has been passed, which sets a quota of 225,000 Aussiedler per year. Finally, in 1996 a German language test has been introduced for potential ethnic German immigrants from the former USSR. Since the introduction of the language test, the acceptance as ethnic German and the issuing of immigration permission is conditioned on the proof of a significant command of the German language (Dietz, 1998). In the case of the New Labor Migrants the quota of immigration permissions under the bilateral agreements have been reduced steadily since 1992. Finally, the end of the civil war in the former Yugoslavia can explain the decreased number of refugees. To summarize, after the heavy inflows of migrants in the early 1990's the German government steadily and successfully increased immigration restrictions.

\subsection{Migration policy in the European context}

Particularly the German asylum policy must be interpreted within the joint migration policy of the European Union. The migration policy of the EU since 1988 is marked by two different developments. First, since the original Treaty of Rome of 1957, internal migration within the EU has been liberalized steadily, finding its conclusion in Article 8a of the Single European Act. This Act requires the achievement of free movement of people, capital, goods and services since January 1, 1993, which implies the abolishment of controls at the interior borders of the EU. Second, with respect to immigration from outside the EU there has been increasing efforts to establish a collective and more restrictive policy. ${ }^{10}$ The necessity of a common EU migration policy was coupled with the plan of a common European market, as 
the abolition of interior borders results in a dependency of each member state on the immigration policy of the other states. The development towards a joint EU migration policy started with the Schengen Accords of June 1985 (Schengen I) and June 19, 1990 (Schengen II) and the accord of Dublin from June 15, 1990, and has been continued with the Maastricht Treaty of 1992.

The main objectives of these initiatives have been the elimination of internal and consistent and tighter external border controls, a unified visa policy, and the coordination of different national asylum policies. For the time being, the final step could be seen in the Treaties from Amsterdam from 1997. Concerning migration policy, Article 63 of the treaty suggests

- a closer co-operation to prevent illegal immigration,

- the elaboration of joint norms regarding the acceptance of asylum seekers, the prerequisites for the immigration and residence of persons from countries outside the EU,

- the alignment of the rights and conditions under with immigrants of one EU member country can reside in another member country.

The Amsterdam Treaty explicitly states, however, that there is no specific time schedule for the resolutions regarding the above stated measures on a joint migration policy.

An upcoming discussion on the migration policy of the EU centers on the planned enlargement towards the Central and Eastern Europe. The EU opened negotiations with several Central and Eastern European countries seeking membership. In principle, all current EU members favor the idea of extending the EU. However, some current members fear that they will lose from this expansion. Countries with direct borders to the potential new EU members, such as Austria and Germany, have expressed the concern of potentially large-scale immigration of job seekers from entering countries into the current EU-member countries.

$10 \quad$ See Zimmermann $(1994,1995)$ for a comprehensive discussion of the immigration policies of the EU and its single members. 
Evaluations of the potential East-West migration flow after an EU-enlargement conclude that East-West migration will reach about 350,000 East-West migrants to the current EU within the first years after enlargement of which about 220,000 will go to Germany (Bauer and Zimmermann, 2000). These flows will decrease over time as the economies of the new member countries converge to those of the current EU-members. Given the German migration experience in the early 1990s, these numbers seem not to be dramatic. Based on the empirical evidence on the labor market effects of immigration, which have been discussed in section 2.2, the wage and employment effects of the predicted inflow are likely to be negligible.

In the short-run, the current EU members have policy options to regulate the potential East-West migration after an enlargement. Similar to the enlargement of the EU towards the south European countries Spain, Portugal and Greece, migration restrictions could be implemented for an adjustment period. At the current stage it seems that such restrictions on labor mobility will be indeed implemented when the Central and Eastern European will join the EU. The main open question is on the duration of these restrictions, which could lie between 5 and 10 years. Because of Article 8a of the single European Act, however, a system of free labor mobility is unavoidable in the long run.

\subsection{Migration policy and the German parties}

It is interesting to examine the migration concepts of the German parties. Until 1998, the CDU/CSU (the conservatives) had governed Germany together with the FDP (some marketoriented liberals), while the SPD (the social-democratic party) and Bündnis 90/Die Grünen (the Greens) where forming the major opposition parties. In 1996, FDP and Bündnis 90/Die Grünen proposed a new immigration law. Both concepts called for an immigration quota and a selection of the immigrants following the Canadian and Australian point system (Frankfurter Allgemeine Zeitung, 1996; Süddeutsche Zeitung, 1995, 1996). This point system 
was supposed to consider humanitarian and economic interests, the demographic development, as well as the situation on the German labor and housing markets. Differences in the proposals of the two parties can be found only in the weighting of the allocation of the points. The Bündnis 90/Die Grünen has given humanitarian reasons and family reunification priority over economic interests. In contrast, the proposal of the FDP has allocated more focus on social and economic aspects.

The SPD has no clear proposal for an immigration policy. Instead, there are two groups within the SPD, which follow different concepts. One group is in favor of an immigration law similar to the point system proposed by FDP and Bündnis 90/Die Grünen. Regarding the allocation of points among different groups of immigrants, the position of this group within the SPD is somewhere in between the positions of the FDP and the Bündnis 90/Die Grünen. The position of the other group within the SPD is more similar to the CDU/CSU, arguing that there is neither a necessity for a new immigration law nor a necessity for additional immigrants. According to their view the existing immigration regulations guarantee a sufficient control of the immigration flows. Furthermore, an immigration law would imply the acceptance of additional migrants. In the face of the high unemployment rates in Germany, immigration in addition to the immigration guaranteed by the existing laws (the immigration of ethnic Germans, war refugees, asylum seekers, and individuals immigrating through the family reunification program), however, could not be justified (see also Kanther, 1996; Hailbronner, 1996). After the SPD won the elections in 1998, the new minister of the interior, Otto Schily, announced that the new government would not prepare a new immigration law in the near future using the argumentation outlined above.

The debate on an immigration law for Germany started again fueled by a speech of the German chancellor Gerhard Schröder in February 2000. In this speech, he promised the German IT-industry to introduce a "green card" for Non-EU IT specialist to meet the excess demand for IT-specialists in Germany and to ensure the development and the competitiveness 
of the German information sector. In May 2000, the German government decided that up to 20.000 Non-EU IT specialists could come to Germany for a period of up to 5 years. In order to immigrate, an applicant must either have a university degree or earn an annual salary of more than DM 100,000 in Germany. The families of the migrants are also allowed to move to Germany. The government has promised that a decision would be reached within a period of one week to meet the competition with other states like the UK or the US. Note that the German green card is more similar to the US H-1B-visa rather than to the US green card, which allows permanent residence.

In early June 2000, 1.400 foreign IT-specialists expressed their interest to come Germany. ${ }^{11}$ It should be noted that soon after the speech of Gerhard Schröder other industries than the information technology sector claimed that they also have an excess demand for skilled workers and that the green card should be extended to satisfy their demands.

Around the discussion on the necessity of a green card for IT-specialists the FDP and the Bündnis 90/Die Grünen again called for the installation of a German immigration law, which follows the Canadian and Australian example. Within the CDU/CSU the positions became rather mixed. Whereas the CDU-politician Jürgen Rüttgers strongly opposed the green card regulation within his campaign for the elections in North Rhine-Westphalia, the CDUpolitician Friedrich Merz and the leader of the federal German state Bavarian, Edmund Stoiber from the CSU, asked for an immigration law, which follows more the demands of the German economy. Both of them, however, claimed that the overall immigration should not be increased through such an immigration law. Rather the immigration of asylum seekers and the immigration within the family reunification program should be reduced in favor of highskilled immigrants. The positions within the SPD again turned out to be diverse. Whereas some SPD-politicians are in favor of a general immigration law, chancellor Schröder stated in May 2000 that the green card regulation is an exception to meet the strong demands in the 
German computer industry and that there will be no immigration law, at least not in the current parliamentary term.

\subsection{German's sentiments towards trade and migration}

The tendency of the main German parties towards a more restrictive immigration policy leads to the question whether the recent globalization process and the huge immigration flows in the early 1990s resulted in rising tensions of the German population against additional immigration and whether these tensions could partly explain the changes in the German migration policy. Table 1 exhibits the share of Germans asking for a total stop of immigration for different immigration groups for the period from 1990 to 1996. It is of particular interest that the development of the tensions against additional immigrants is different between West and East Germany. Whereas the share of West Germans opting for a total stop of immigration is constant or decreasing between 1990 and 1996, the share of East Germans opting for a total stop is sharply increasing for all groups of immigrants. Since the East Germans experienced a sharp increase of unemployment and inequality since the re-unification, the latter result seems to support the arguments of Williamson (1998). Empirical studies of attitudes towards foreigners show that negative sentiments towards foreigners are decreasing with education and occupational status and increasing with age. However, the results regarding the effect of being unemployed are mixed. ${ }^{12}$

Bauer, Lofstrom and Zimmermann (2000) analyze the interaction between immigration policy and natives' sentiments towards immigrants in 12 OECD-countries. In general, it is difficult to disentangle to what extent the sentiments of the population are in line with policy or policy is in line with sentiments. They think, however, that there are indications that immigration policies affect natives' sentiments of immigrants. Analyzing individual data

11202 of these specialists come from Bulgaria, 121 from India, 81 from Ecuador, 75 from Hungary, 71 from Russia and 70 from Algeria. 
from 12 OECD countries, Bauer, Lofstrom and Zimmermann (2000) find that natives in countries selecting immigrants on their skills, such as Canada, Australia and New Zealand, are more likely to think that immigrants are generally good for the economy than in countries that receive mainly asylum seekers and refugees. Natives in Canada and New Zealand, however, are more concerned that immigration negatively affects their own labor market situation, whereas in countries that receive mainly non-economic migrants, natives are mostly concerned about increasing crime rates.

Policy-makers are typically concerned about re-election, and hence must be interested in the emotions of voters caused by immigration. There are two important channels by which re-election might be affected: First, there are social tensions caused by ethnic rivalry and other negative social externalities such as crime. Second, immigration can improve the economic conditions in a country. Since the popularity of a government depends largely on its economic success, a well-chosen migration policy can be effective.

The question arises, if the fears of individuals are also revealed by their voting behavior. Tables 2 and 3 explore the voting behavior of individuals and their sentiments towards immigration and imports for Germany and the US. The data comes from the International Social Survey Programme (ISSP), which is a continuing annual program of cross-national collaboration on surveys covering a variety of topics deemed important for social science research. In 1995, ISSP compiled representative cross-national data on national identity, which included questions about the perception of immigrants, immigration and imports.

A clear result from Tables 2 and 3 is that the majority of individuals in Germany and the US think that immigration should be reduced. About $76 \%$ of the individuals in West Germany and $80 \%$ of the individuals in East Germany think that immigration should be countries. See Gang and Rivera-Batiz (1994) for further evidence on Germany and Dustmann and Preston (1998) for the UK. 
reduced. The corresponding number for the US is somewhat lower; only $64 \%$ of individuals in the US think that immigration should be more restrictive. In the US, however, significantly more individuals agree that imports of foreign products should be limited in order to protect the national economy than in Germany. Whereas $69 \%$ of individuals in the US think that imports should be limited, only $41 \%$ of West Germans and $58 \%$ of East Germans opt for a limitation of imports. Overall, Tables 2 and 3 are in line with the arguments of Williamson (1998), since the majority of the population in Germany and the US seems to opt for both, a more restrictive immigration and trade policy.

\section{InTERNATIONAL COMPETITION FOR High-SKILled WORKERS AND THE NEED FOR A Change in Migration Policies}

So far, the discussion has shown that the globalization process will most likely result in increased immigration flows to the developed countries, at least in the short and medium run, and that trade and immigration could potentially lead to increased income inequality or to a rise in the unemployment of unskilled workers, even though the empirical evidence regarding the latter is mixed. Most countries facing this development have reacted with increasing restrictions on immigration. However, we must ask whether this restrictive policy is the right way to deal with the effects of globalization. A total restriction of free labor mobility will not solve the problems of unskilled workers resulting from liberalized trade, since it does not alter the effects of liberalized trade. Furthermore, such a policy would lead to an increased immigration pressure resulting in high costs for the respective countries to protect their borders. In addition, a restrictive immigration policy might lead to the effect that the production of low-skilled intensive goods will be transferred to developing countries.

One alternative policy would be, to allow free global mobility of labor across countries instead of restricting migration. In the short and medium run this will most likely lead to an increased immigration of unskilled workers resulting in increased inequality and/or higher 
unemployment of unskilled workers in the developed countries. In the long run, factor prices across countries will tend to equalize and the incentives for migration will disappear. However, it is doubtful, whether the increasing social tensions arising from such a development will allow the respective governments to sustain such a policy long enough for factor prices to equalize. Again, this policy is not able to solve the problems of increasing inequality or increasing unemployment of unskilled workers.

A second alternative policy option would be a selective immigration policy by restricting the immigration of unskilled workers and promoting the immigration of skilled workers. This policy will lead to an increased supply of skilled workers in the developed countries, which lowers wages for this type of workers and decrease the current excess demand for skilled workers. Such a policy could foster the specialization of the countries in their production, i.e. developed countries will specialize more in the production and development of skilled intensive goods such as IT-technology or biological technology and less developed countries will specialize more in the production of unskilled-intensive goods.

Such a selective migration policy towards high skilled migrants is reflected in the immigration debate in most important receiving countries. As already described above, the German government wants to introduce a green card for foreign IT-specialist to meet the excess demand for IT-workers in Germany. Similarly, U.S. senators Orin Hatch and Spencer Abraham recently introduced a bill that would increase the number of H-1B visas, six-year temporary visas granted to foreigners with college degrees, from 115,000 to 195,000 for the next three years. Australia, Canada and New Zealand use a point system to select migrants, which are of particular need in their labor markets. It seems that the international competition of the developed countries for high skilled workers is becoming more severe. Especially in labor markets and economies where the necessities of different types of human capital change frequently, it seems to be essential to attract foreign workers with the human capital in 
demand, since national educational systems are unable to react fast enough to the changing human capital requirements.

The lesson for policy-makers is quite simple: A government would be more popular if it chooses migrants more according to the labor market needs, because this moderates social tensions and increases the economic performance of the country. The current outcry in Germany to provide green cards to non-EU IT specialists to save the development of the German information sector is just a simple example of this.

Two main questions remain for the case of a selective immigration policy. First, how should such a selective migration policy be organized? In general, there are two possibilities. (See Bauer (1998) and Bauer and Zimmermann (1999) for a detailed discussion.) The first is to adopt a point system, similar to those in Canada, Australia, and, more recently, in Switzerland. The main deficiencies of this policy are (i) that the existing management techniques of a point system are not able to address unexpected events, like recessions; (ii) that due to the time lag between collecting and analyzing labor market data on occupational shortages, and the actual landing of immigrants could lead to the selection of the wrong migrants; and (iii) that there are no reliable empirical techniques to identify shortages in particular occupations.

The second possibility is to auction the right to immigrate to potential migrants or to domestic firms. The concept to auction the right to immigrate or the right to select a migrant is quite appealing to economists, because an auction selects migrants or firms according to their abilities or needs and their willingness to pay. This selection mechanism will efficiently identify those migrants or firms with the largest potential for the economy. A point system also discriminates among migrants by their economic value, but an auction will in addition self-select those persons who have the best chance to achieve economic success. In general, this holds irrespective whether the immigration visas are auctioned to potential migrants or to native firms. A main drawback, however, is the costs, which are imposed on the migrants. If 
several countries compete for a high-skilled migrant, this migrant will move to the country where he/she could expect the highest income gains. Since an auction increases the costs of migrating, this migrant has a higher probability to migrate to a country, which does not allocate immigration visas using an auction. Auctions among firms have the advantage that firms know probably better what types of jobs are really at demand in a country. However, this knowledge is probably only of value in the short run. Hence, it might be best after all to auction only among firms in the context of a temporary immigration regime. For permanent immigration, it might be better to apply a point system to avoid a negative self-selection of migrants that seek welfare benefits.

The second main question is, whether the receiving country should allow permanent or only temporary migration. Permanent migration normally implies that selected high-skilled workers will immigrate together with their family. However, empirical evidence suggests that the family members could end up as unskilled workers that would result in similar problems as under an unregulated immigration regime. This problem could be avoided by allowing only temporary migration, since a government could then restrict the immigration of family members more easily.

\section{ConClusion}

Globalization (especially trade and its labor content) and migration are two sides of the same coin that will be used to shape the future of the western economies. The most crucial threat of globalization is virtual migration through the Internet. While the immediate pressure is currently on the labor market of the low-skilled, virtual migration will also affect the skilled labor markets. Hence, there is no way to ignore the pressure. We have argued that the best response is to open up the economies as far as possible to speed up the adjustment processes in the countries and to enable new market forces to develop new products and employ both skilled and low-skilled workers. Selective immigration policies are a first step in this direction 
that allow to test the respective strategies and to convince voters that integrated national economies are in the best interest of the countries. 


\section{REFERENCES}

Bauer, T. (1998): Arbeitsmarkteffekte der Migration und Einwanderungspolitik. Heidelberg: Physica-Verlag.

Bauer, T., B. Dietz, K. F. Zimmermann, and E. Zwintz (1998): "Migration: The German Case," mimeo., IZA, Bonn.

Bauer, T., and K. F. Zimmermann (1997): "Integrating the East: The Labor Market Effects of Immigration," in S. Black (ed.): Europe's Economy Looks East: Implications for Germany and the EU. Cambridge: Cambridge University Press, 269-306.

Bauer, T., and K. F. Zimmermann (1998): "Causes of International Migration: A Survey," in C. Gorter, P. Nijkamp, and J. Poot (eds.): Crossing Borders: Regional and Urban Perspectives on International Migration. Aldershot et.al.: Ashgate, 95-127.

Bauer, T., and K. F. Zimmermann (1999): "Assessment of possible Migration Pressure and its Labour Market Impact follwoing EU Enlargemnt to Central and Eastern Europe: Part 2," DfEE Research Report RR 139. London: Department for Education and Employment.

Bauer, T., M. Lofstrom and K. F. Zimmermann (2000): "Immigration Policy, Assimilation of Immigrants and Natives' Sentiments towards Immigrants: Evidence from 12 OECDcountries," mimeo., Bonn: IZA.

Bhagwati, J., and V. Dehejia (1994): "Free Trade and Wages of the Unskilled: Is Marx Striking Again?" in: Bhagwati, J., and M. Kosters (eds.): Trade and Wages. Washington D.C.: American Enterprise Institute, 36-75.

Borjas, G., R. B. Freeman, and L. Katz (1992): "On the Labor Market Effects of Immigration and Trade," in G. Borjas and R. B. Freeman (eds.), Immigration and the Work Force. Chicago: University of Chicago Press, 213-244.

Brecher, R. A., and E. U. Choudhri (1987): "International Migration versus Foreign Investment in the Presence of Unemployment," Journal of International Economics, 23, 329-342.

Dietz, B. (1998): "Ethnic German Immigrants from Eastern Europe and the former Soviet Union in Germany: The Effects of Migrant Networks," mimeo., Osteuropa-Institut, München.

Dustmann, C., and I. Preston (1998): "Attitudes to Ethnic Minorities, Ethnic Context and Location Decisions," paper presented at the CEPR conference Metropolitan Economic Performance, Lisbon (Portugal), October 1998.

Feenstra, R. C. (1998): "Integration of Trade and Disintegration of Production in the Global Economy," Journal of Economic Perspectives, 12, 31-50.

Freeman, R. B. (1995): “Are Your Wages Set in Beijing?", Journal of Economic Perspectives, Vol. 9 (3), 15-32.

Friedberg, R. M., and J. Hunt (1995): "The Impact of Immigrants on Host Country Wages, Employment and Growth," Journal of Economic Perspectives, 9, 23-44.

Gang, I., and F. Rivera-Batiz (1994): "Unemployment and Attitudes Towards Foreigners in Germany," in G. Steinmann and R. Ulrich (eds.): The Economic Consequences of Immigration to Germany. Heidelberg: Physica-Verlag, 121-154.

Hailbronner, K. (1996): „Es bleibt nicht viel zu regeln übrig,“ Frankfurter Allgemeine Zeitung, 26. April 1996, Nr. 98, 14.

Haisken-DeNew, J. P., and K. F. Zimmermann (1997): "Wage and Mobility Effects of Trade and Migration," forthcoming in W. Dewatripont and A. Sapir (eds.), International Trade and Employment: The European Experience. Oxford: Oxford University Press.

Kanther, M. (1996): „Deutschland ist kein Einwanderungsland,“ Frankfurter Allgemeine Zeitung, 13. November 1996, Nr. 265, 11. 
Lederer, H. W. (1997): Migration und Integration in Zahlen: Ein Handbuch. Bonn: Beauftragte der Bundesregierung für Ausländerfragen.

Lücke, M. (1996): Has Trade with Low-Wage Countries Hurt Unskilled Labor in West Germany? mimeo., Kiel, Institute of World Economics.

Martin, P.L., and J. E. Taylor (1996): "The Anatomy of a Migration Hump," in OECD (ed.): Development Strategy, Employment and Migration. Paris: OECD.

Massey, D. S. (1990): "Social Structure, Household Strategies, and the Cummulative Causation of Migration," Population Index, 56, 1-26.

OECD (1998): SOPEMI - Trends in International Migration: Annual Report. Paris: OECD.

Rotte, R., and M. Vogler (1998): "Determinants of International Migration: Empirical Evidence for Migration from Developing Countries to Germany," IZA Discussion Paper No. 12, Bonn.

Sachs, J., and H. Shatz (1994): "Trade and Jobs in U.S. Manufacturing," Brookings Papers on Economic Activity, 1, 1-84.

Schiff, M. (1996): "Trade Policy and International Migration: Substitutes or Complements?" in OECD (ed.): Development Strategy, Employment and Migration. Paris: OECD, 2341.

Schmidt, C. M., A. Stilz, and K. F. Zimmermann (1994): "Mass Migration, Unions, and Government Intervention," Journal of Public Economics, 55, 185-201.

Stark, O. (1991): The Migration of Labor. Oxford: Basil Blackwell.

Williamson, J. G. (1998): "Globalization, Labor Markets and Policy Backlash in the Past," Journal of Economic Perspectives, 12, 51-72.

Winter-Ebmer, R., and K. F. Zimmermann (1998): "East-West Trade and Migration: The Austro-German Case," IZA Discussion Paper No. 2, IZA, Bonn.

Wood, A. (1994): North-South Trade, Employment and Inequality. Oxford: Clarendon Press.

Wood, A. (1995): "How Trade Hurt Unskilled Workers," Journal of Economic Perspectives, 9, 57-80.

Zimmermann, K. F. (1994): “The Labour Market Impact of Immigration,” in S. Spencer (ed.): Immigration as an Economic Asset: The German Experience. Stoke-on-Trent: Trentham Books.

Zimmermann, K. F. (1995): "Tackling the European Migration Problem," Journal of Economic Perspectives, 9, 45-62.

Zimmermann, K. F. (1997): "Die Einwanderungskonsequenzen unterschiedlicher Einwanderungspolitiken," in D. Sadowski and K. Pull (eds.), Vorschläge jenseits der Lohnpolitik - Optionen für mehr Beschäftigung II. Frankfurt, New York: Campus, 297-316. 
Table 1: Share of Germans, Asking for a Total Stop of Immigration*

\begin{tabular}{|c|c|c|c|c|}
\hline & 1990 & 1991 & 1992 & 1996 \\
\hline \multicolumn{5}{|l|}{ Aussiedler from East Europe } \\
\hline West Germany & 20.4 & 10.1 & 10.1 & 11.5 \\
\hline East Germany & - & 11.9 & 10.9 & 17.7 \\
\hline \multicolumn{5}{|l|}{ Asylum Seekers } \\
\hline West Germany & 30.4 & 21.6 & 23.8 & 21.7 \\
\hline East Germany & - & 15.2 & 18.1 & 21.1 \\
\hline \multicolumn{5}{|l|}{ Labor Immigrants from the EU } \\
\hline West Germany & 13.3 & 9.8 & 9.0 & 12.1 \\
\hline East Germany & - & 25.5 & 24.0 & 37.7 \\
\hline \multicolumn{5}{|c|}{ Labor Immigrants from outside the EU } \\
\hline West Germany & 34.1 & 28.4 & 28.1 & 31.3 \\
\hline East Germany & - & 39.3 & 36.1 & 49.3 \\
\hline
\end{tabular}

Source: ALLBUS, own calculations. 


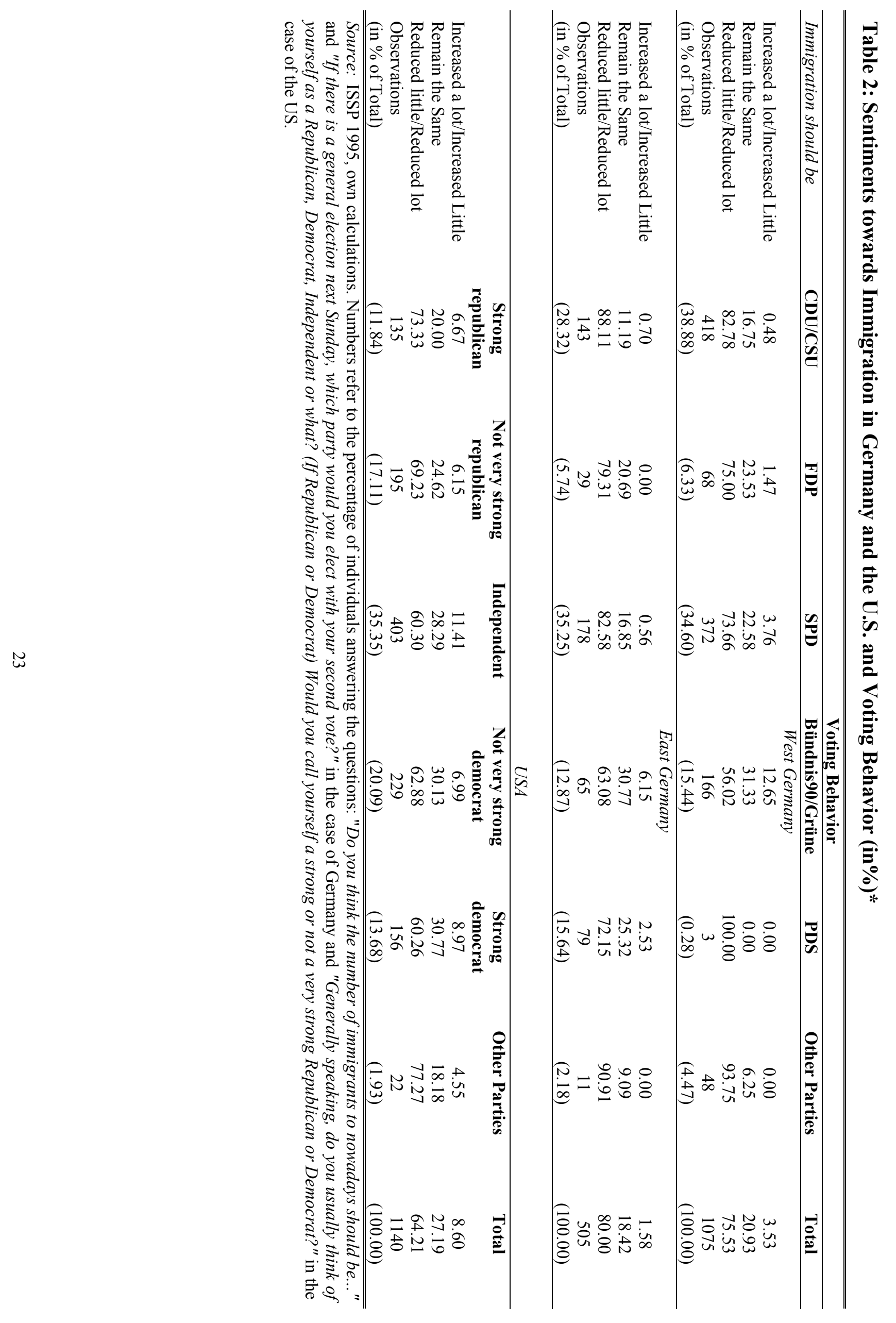




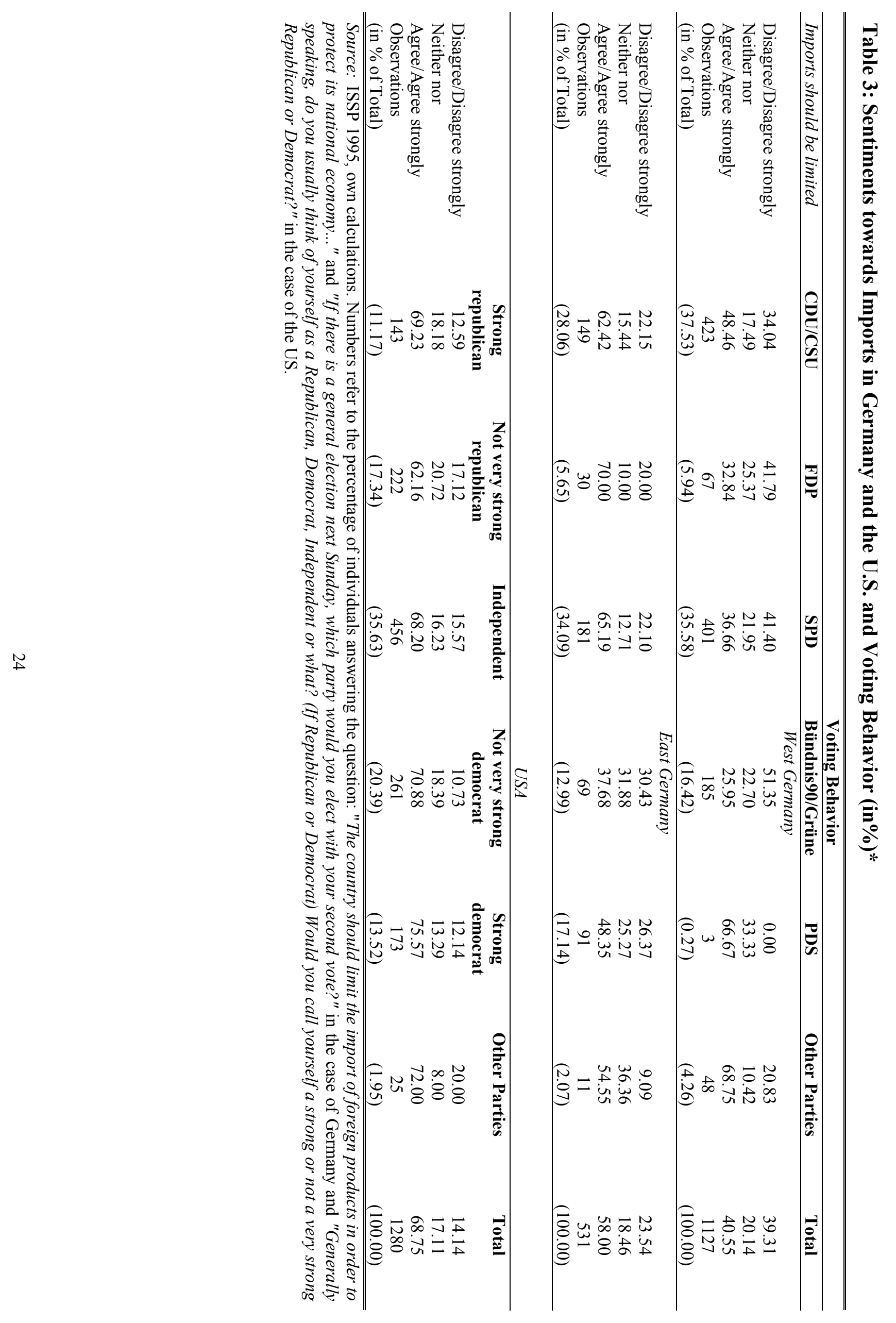


Figure 1: Immigration of Foreigners in Selected OECD Countries

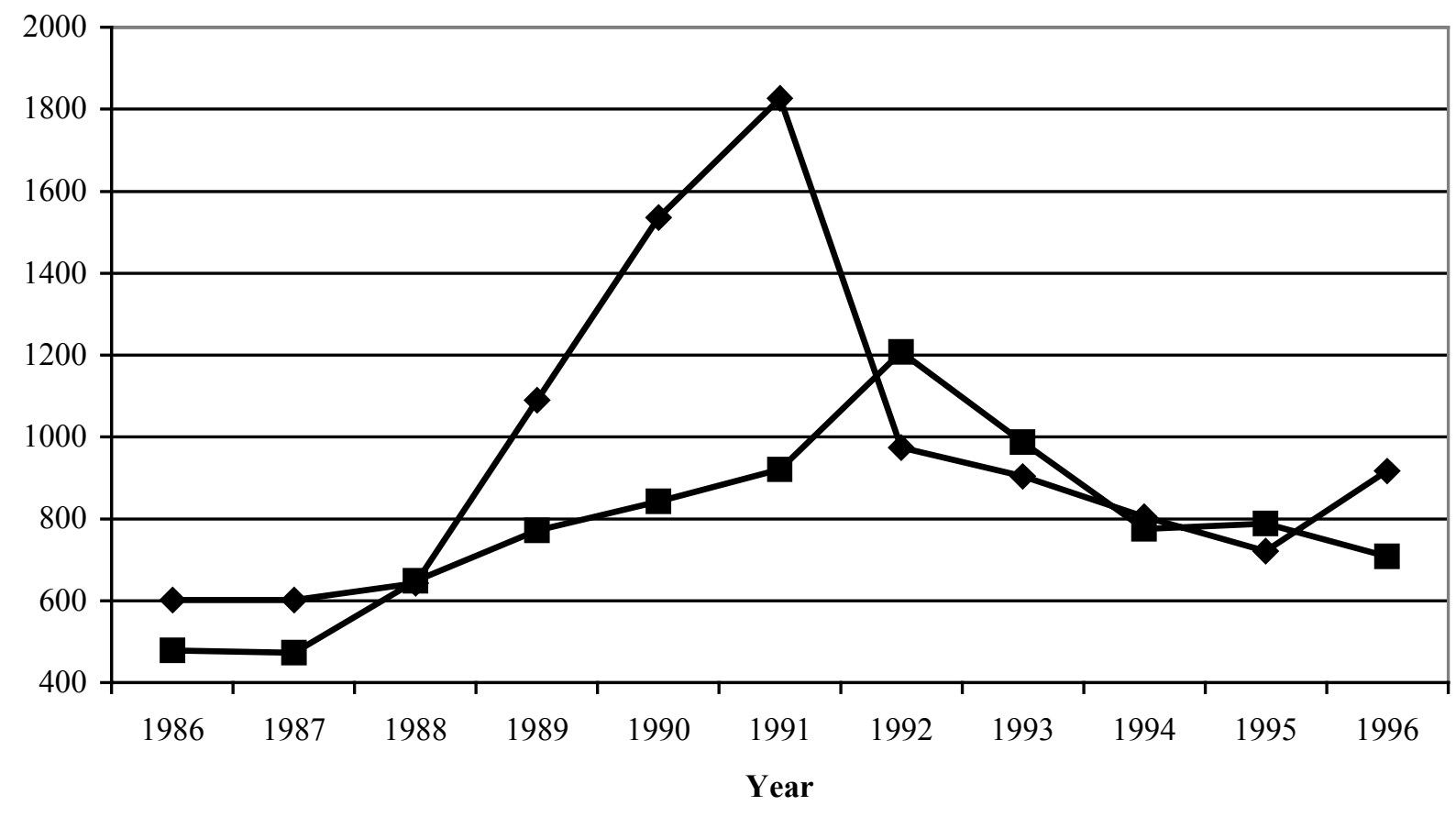

-United States $\rightarrow$ Germany

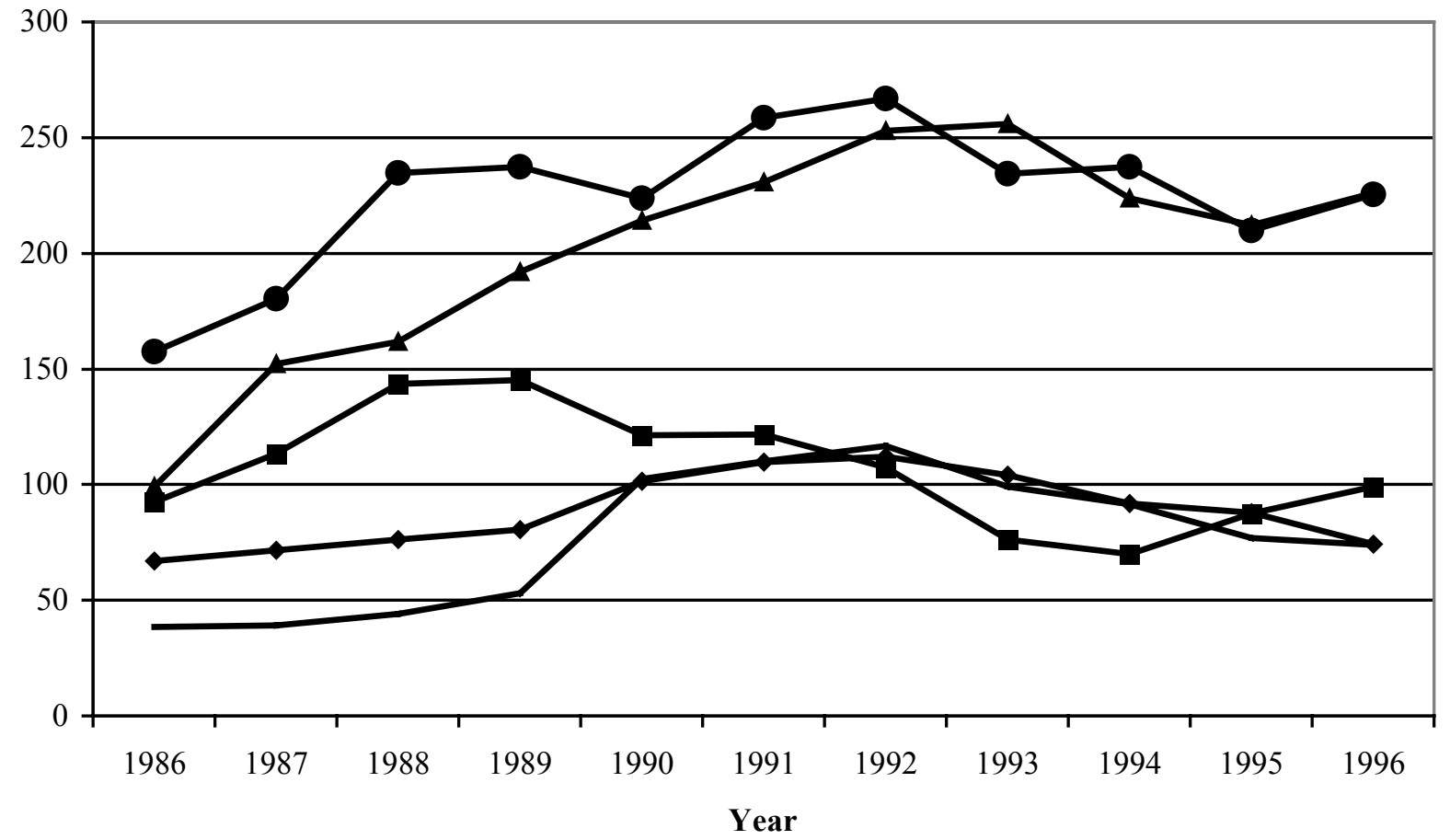

$\rightarrow$ Australia $\rightarrow$ Canada $\longrightarrow$ Switzerland $\longrightarrow$ France $\longrightarrow$ Japan

Source: OECD (1998) 
Figure 2: Immigration to Germany by Immigration Status (1980-1996)

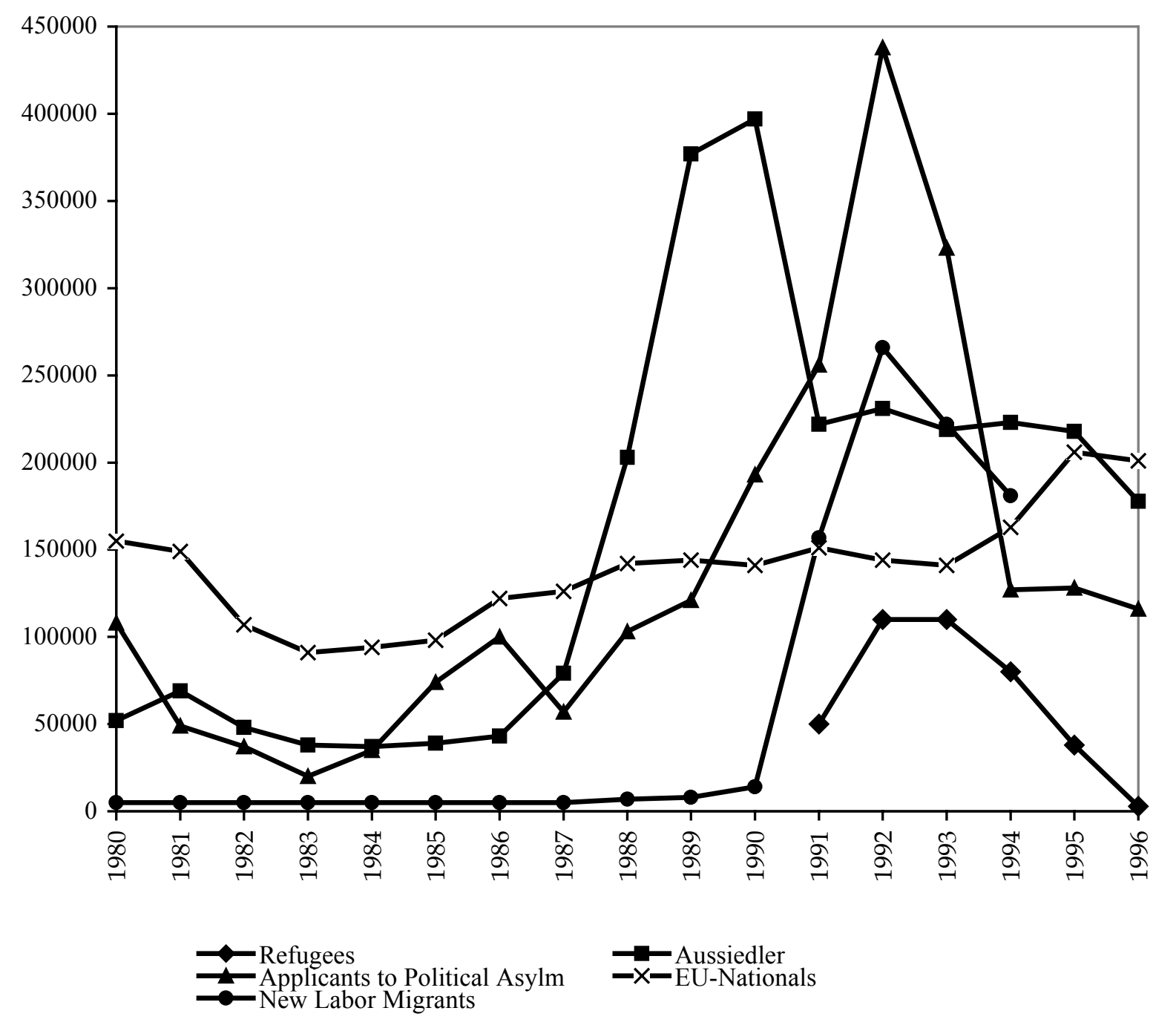

Source: Lederer (1997). 


\section{IZA Discussion Papers}

No. Author(s)

71

72

L. Goerke

J. Fersterer

R. Winter-Ebmer

73

G. S. Epstein

S. Nitzan

74 M. Kräkel

75

B. Henry

M. Karanassou

D. J. Snower

76

G. Brunello

M. Giannini

77

C. M. Schmidt

78

J. Hansen

R. Wahlberg

79

J. S. Earle

Z. Sakova

80 J. C. van Ours

J. Veenman

81

T. J. Hatton

S. Wheatley Price

82 K. A. Konrad

83

R. Euwals

84

C. M. Schmidt

85 S. Pudney

M. A. Shields

86

J.P. Haisken-DeNew

C. M. Schmidt

87
Title

Area

Date

The Wedge

3

$11 / 99$

Are Austrian Returns to Education Falling Over

Time?

The Endogenous Determination of Minimum Wage 3

Strategic Mismatches in Competing Teams

5

Adjustment Dynamics and the Natural Rate: An 1

Account of UK Unemployment

Selective Schools

5

Knowing What Works: The Case for Rigorous

Program Evaluation

Endogenous Schooling and the Distribution of the Gender Wage Gap

Entrepreneurship from Scratch: Lessons on the Entry Decision into Self-Employment from Transition Economies

The Netherlands: Old Emigrants - Young Immigrant Country

Migration, Migrants and Policy in the United Kingdom

Privacy, time consistent optimal labor income taxation and education policy

Female Labour Supply, Flexibility of Working Hours, 1 and Job Mobility in the Netherlands

The Heterogeneity and Cyclical Sensitivity of 1 Unemployment: An Exploration of German Labor Market Flows

Gender and Racial Discrimination in Pay and 5/6 Promotion for NHS Nurses

Money for Nothing and Your Chips for Free?

5 The Anatomy of the PC Wage Differential

Educational Mismatch and Wages in Germany
5

$11 / 99$

$11 / 99$

$12 / 99$

$12 / 99$

$12 / 99$

$12 / 99$

$12 / 99$

$12 / 99$

$12 / 99$

$12 / 99$

$12 / 99$

$12 / 99$

12/99

$12 / 99$

$12 / 99$

$12 / 99$ 
P. Cahuc

A. Zylberberg

97

A. Barrett

98

J.P. Haisken-DeNew

C. M. Schmidt

L. Husted

H. S. Nielsen

M. Rosholm

N. Smith
G. Brunello
C. Graziano
B. Parigi

Migration in Spain: Historical Background and 1 Current Trends

Aliyah to Israel: Immigration under Conditions of 1 Adversity

Tenures that Shook the World: Worker Turnover in $\quad 4$ Russia, Poland and Britain

Identification and Estimation of Causal Effects of 6 Multiple Treatments Under the Conditional Independence Assumption

The Rate of Return to Private Schooling

An Evaluation of Public-Sector-Sponsored

\section{Germany}

An Evaluation of Public Employment Programmes 6 in the East German State of Sachsen-Anhalt

Job Protection, Minimum Wage and Unemployment 3

Irish Migration: Characteristics, Causes and 1

Industry Wage Differentials Revisited: A

Longitudinal Comparison of Germany and USA

Residential Location and Youth Unemployment: 1

The Economic Geography of School-to-Work-

Transitions

Immigrant Assimilation and Welfare Participation: 1/3

Do Immigrants Assimilate Into or Out-of Welfare?

Employment and Wage Assimilation of Male First 3 Generation Immigrants in Denmark

Labor Supply and Matching Rates for Welfare

Characteristics

Estimation in a Duration Model for Evaluating

Matching Model with Uncertainty -

An Extension of Mortensen and Pissarides (1994)

Ownership or Performance: What Determines 1 
1979 - 1990: An analysis of the (West-)German multivariate failure times and unobserved heterogeneity

107 J. C. van Ours G. Ridder

J. Boone

J. C. van Ours

G. J. van den Berg

B. van der Klaauw

110 D. DeVoretz

C. Werner

111 V. Sorm

K. Terrell

L. Bellmann

T. Schank

113 R. Euwals

114 G. Brunello

A. Medio

115 A. Cigno

F. C. Rosati

116 C. Belzil

117 S. Bender

A. Haas

C. Klose

118 M. A. Shields

M. E. Ward

119 A. Lindbeck

D. J. Snower

120 P. T. Pereira

P. S. Martins

121 J. C. van Ours

122 D. Munich

J. Svejnar

K. Terrell

123 J. Hunt
Fast Track or Failure: A Study of the Completion

Rates of Graduate Students in Economics

Modeling Financial Incentives to Get Unemployed Back to Work

Combining Micro and Macro Unemployment

Duration Data

A Theory of Social Forces and Immigrant Second

Language Acquisition

Sectoral Restructuring and Labor Mobility:

A Comparative Look at the Czech Republic

Innovations, Wages and Demand for

Heterogeneous Labour: New Evidence from a

Matched Employer-Employee Data-Set

Do Mandatory Pensions Decrease Household

Savings? Evidence for the Netherlands

An Explanation of International Differences in

Education and Workplace Training

Why do Indian Children Work, and is it Bad for

Them?

Unemployment Insurance and Subsequent Job

Duration: Job Matching vs. Unobserved

Heterogeneity

IAB Employment Subsample 1975-1995.

Opportunities for Analysis Provided by the

Anonymised Subsample

Improving Nurse Retention in the British National

Health Service: The Impact of Job Satisfaction on

Intentions to Quit

The Division of Labor and the Market for

Organizations

Does Education Reduce Wage Inequality?

Quantile Regressions Evidence from Fifteen

European Countries

Do Active Labor Market Policies Help Unemployed Workers to Find and Keep Regular Jobs?

Returns to Human Capital under the Communist

Wage Grid and During the Transition to a Market

Economy

Why Do People Still Live in East Germany?
3

5

$2 / 00$

5

$2 / 00$

5

$2 / 00$

$1 / 00$

$1 / 00$

$1 / 00$

$2 / 00$

$2 / 00$

$2 / 00$

$2 / 00$

$2 / 00$

$2 / 00$

$2 / 00$

$2 / 00$

7

/00

$3 / 00$

$4 / 6$

4

$3 / 00$ 
Rational Poverty or Poor Rationality? The Take-up

125 F. Büchel

J. R. Frick

of Social Assistance Benefits

The Income Portfolio of Immigrants in Germany - $\quad 1 / 3$

$3 / 00$

Effects of Ethnic Origin and Assimilation. Or:

Who Gains from Income Re-Distribution?

126 J. Fersterer

R. Winter-Ebmer

Smoking, Discount Rates, and Returns to

Education

127 M. Karanassou

D. J. Snower

Characteristics of Unemployment Dynamics: The

Chain Reaction Approach

128 O. Ashenfelter

Do Unemployment Insurance Recipients Actively

Seek Work? Evidence From Randomized Trials in

D. Ashmore

O. Deschênes

129 B. R. Chiswick

M. E. Hurst

130 G. Brunello

S. Comi

C. Lucifora

Four U.S. States

The Employment, Unemployment and

Unemployment Compensation Benefits of

$1 / 3 \quad 3 / 00$

Immigrants

The Returns to Education in Italy: A New Look at $5 \quad 3 / 00$

the Evidence

Are Immigrants Favorably Self-Selected? An $\quad 1 \quad 3 / 00$

Economic Analysis

Hours and Wages in the Depression: British $7 \quad 3 / 00$

Engineering, 1926-1938

Paid and Unpaid Overtime Working in Germany and $1 \quad 3 / 00$

133 D. N. F. Bell

R. A. Hart

O. Hübler

W. Schwerdt

134 A. D. Kugler

G. Saint-Paul

135 A. Barrett

P. J. O'Connell

the UK

Hiring and Firing Costs, Adverse Selection and

3

$3 / 00$

Long-term Unemployment

Is There a Wage Premium for Returning Irish

1

$3 / 00$

Migrants?

136 M. Bräuninger

M. Pannenberg

Unemployment and Productivity Growth: An

3

$3 / 00$

Empirical Analysis within the Augmented Solow

Model

137 J.-St. Pischke

Continuous Training in Germany

$3 / 00$

138 J. Zweimüller

R. Winter-Ebmer

Firm-specific Training: Consequences for Job

Mobility

139 R. A. Hart

Y. Ma

Wages, Hours and Human Capital over the

Life Cycle

5

$3 / 00$

Education and Earnings Growth: Evidence from 11

European Countries

The Effects of Public Sector Sponsored Training on

Individual Employment Performance in East

$4 / 00$ 

both Worlds?

$\begin{array}{cl}145 & \text { M.-S. Yun } \\ 146 & \begin{array}{l}\text { T. K. Bauer } \\ \text { J.P. Haisken-DeNew }\end{array} \\ 147 & \begin{array}{l}\text { M. Belot } \\ \text { J. C. van Ours }\end{array}\end{array}$

Decomposition Analysis for a Binary Choice Model

Does the Recent Success of Some OECD

Microeconometric Evaluation of the Active Labour 6 Market Policy in Switzerland

The Duration of Immigrants' Unemployment Spells: $\quad 1 / 3 \quad 5 / 00$

155 J. Hansen

156 C. Dustmann Evidence from Sweden

Language Proficiency and Labour Market Per- 1

M. Jäntti

O. Raaum

E. Österbacka

Finland, Norway and Sweden Compared to the United States 
A Comparison of the Human Capital and Signaling Models: The Case of the Self-Employed and the Increase in the Schooling Premium in the 1980's

161 V. Gimpelson

Public Employment and Redistributive Politics:

4

D. Treisman

Evidence from Russia's Regions

G. Monusova

162 C. Dustmann

M. E. Rochina-

Selection Correction in Panel Data Models: An

6

$6 / 00$

Barrachina

Application to Labour Supply and Wages

163 R. A. Hart

Y. Ma

Why do Firms Pay an Overtime Premium?

5

$6 / 00$

164 M. A. Shields

Racial Harassment, Job Satisfaction and Intentions

5

$6 / 00$

S. Wheatley Price

to Quit: Evidence from the British Nursing Profession

165

P. J. Pedersen

Immigration in a High Unemployment Economy:

$6 / 00$

166 Z. MacDonald The Recent Danish Experience

The Impact of Alcohol Consumption on Occupa- 5 tional Attainment in England

167 A. Barrett

J. FitzGerald

Earnings Inequality, Returns to Immigration into Ireland

B. Nolan

168 G. S. Epstein

A. L. Hillman

Social Harmony at the Boundaries of the Welfare 3

State: Immigrants and Social Transfers

New Zealand and Australia

170 T. K. Bauer

Immigration Policy in Integrated National Economies $\quad 1$

$7 / 00$ 